\title{
THE
}

\section{A new decade of uses for geographic information systems (GIS) as a tool to research, measure and analyze library services}

\author{
Lauren H. Mandel \\ University of Rhode Island, lauren_mandel@uri.edu \\ Bradley Wade Bishop \\ Ashley Marie Orehek
}

Follow this and additional works at: https://digitalcommons.uri.edu/lsc_facpubs

The University of Rhode Island Faculty have made this article openly available.

Please let us know how Open Access to this research benefits you.

This is a pre-publication author manuscript of the final, published article.

Terms of Use

This article is made available under the terms and conditions applicable towards Open Access Policy Articles, as set forth in our Terms of Use.

\section{Citation/Publisher Attribution}

Mandel, L.H., Bishop, B.W. and Orehek, A.M. (2020), "A new decade of uses for geographic information systems (GIS) as a tool to research, measure and analyze library services", Library Hi Tech, Vol. ahead-ofprint No. ahead-of-print. https://doi.org/10.1108/LHT-03-2020-0052

Available at: https://doi.org/10.1108/LHT-03-2020-0052

This Article is brought to you for free and open access by the Graduate School of Library and Information Studies at DigitalCommons@URI. It has been accepted for inclusion in Graduate School of Library and Information Studies Faculty Publications by an authorized administrator of DigitalCommons@URI. For more information, please contact digitalcommons@etal.uri.edu. 


\section{A New Decade of Uses for Geographic Information Systems (GIS) as a Tool to Research, Measure, and Analyze Library Services}

\begin{tabular}{|r|l|}
\hline Journal: & Library Hi Tech \\
\hline Manuscript ID & LHT-03-2020-0052.R2 \\
\hline Manuscript Type: & Original Article \\
\hline Keywords: & $\begin{array}{l}\text { GIS, Geographic information systems, spatial analysis, library service } \\
\text { areas, library facilities management, Collections management }\end{array}$ \\
\hline \multicolumn{2}{|l}{} \\
\hline
\end{tabular}

\section{SCHOLARONE \\ Manuscripts}




\section{A new decade of uses for geographic information systems (GIS) as a tool to research, measure, and analyze library services}

\section{Introduction}

Ten years ago, a literature review explored library research that utilized geographic information systems (GIS) as a tool to measure and analyze library services (Bishop and Mandel, 2010). The original review's purpose was to determine the work that had been done in libraries since the advent of GIS and establish future directions for the research area. GIS "are the collection of hardware, software, output devices and practices are that used to analyse and map spatial entities and their relationships" (Schuurman, 2009, p. 277). "If one considers productivity software (e.g., Microsoft Word) as central to processing, manipulating, and visualizing textual information, then a GIS (e.g., ArcGIS) is central to processing, manipulating, and visualizing GI" (Bishop and Grubesic, 2016, p. 22).

Ten years of advancement in technology, increased availability of geospatial data, and increased education of GIS in library and information science programs provided incentive to revisit this topic and compare changes (Bishop and Grubesic, 2016). GIS, the study of its uses, geographic information science, and the many domains that use GIS has greatly expanded. In the last decade, there has been greater functionality of web-based mapping applications, location-based applications on mobile devices, and expanded and democratized access to the creation and use of geospatial data. For example, Google's MyMaps package allows anyone with a Google account to create a map using street addresses. This does not require specialized cartographic knowledge, and it results in maps that lack traditional cartographic elements like a legend. Figure 1 shows an example of a map depicting the locations of all public libraries in Rhode Island, with using address data pulled from the IMLS Public Library dataset. This increase in access to geospatial data gives libraries and their communities more power to shape the world around them, but not embracing this potential empowerment might lead to marginalization (Byrne and Pickard, 2016). Figure 2 uses GIS to visually compare the square footage of public libraries in Davidson County, Tennessee with the size of the African American population served by those library facilities. Libraries need to remain on the map and this literature review provides some examples of what research has been conducted in the last ten years to that end.

Figure 1. Map of Rhode Island public library locations. <insert Figure 1 here>

Figure 2. Map of Davidson County, TN public library facility sizes and African American population served. <insert Figure 2 here> 
The one constant of GIS over these past years remains the multitude of meanings and uses. One GIS literature review showed a high degree of crossfertilization of ideas, methods, and approaches in numerous fields-all linked by the versatility of geospatial technologies (Wei et al., 2015). That literature review searched "geographic information systems" in all three Web of Science (WOS) indices (i.e., Citation Index Expanded (SCI-EXPANDED), the Social Science Citation Index (SSCl), and the Art \& Humanities Citation Index (A\&HCI)) over the years 2003-2012 and retrieved 3,290 articles. To conduct a review of the studies that used GIS as a tool in library research requires a more manual approach. There are expanding roles for information professions related to digital curation of geospatial data, but those papers are outside the scope of this review. The purpose of this research paper is to update the exploration of library research that employs GIS as a tool to measure and analyze library services in order to assess the current trends of this research area, and, a decade later, to again suggest new directions.

\section{Background}

Roger Tomlinson (1998) coined the term "geographic information systems" while leading the first industry-scale computer-based GIS, known as the Canadian Geographic Information System in the early 1960s (Wade and Sommer, 2006). Nearly thirty years of advancement in the technology and methods using GIS led to Michael Goodchild (1992) proposing "Geographic Information Science" as a term that encompasses the scientific questions, methods, and knowledge that transcend the technology of any particular geographic information system. This contribution conflated the use of the term as the common acronym in geography (i.e., GIS) now meant at least both things to the same community. The term is further complicated in a literature review of library research due to the fact that information professionals also provide services and resources related to organizing, accessing, and using geospatial data (Bishop and Grubesic, 20016). The collective term for this part of GIS in library literature is geographic information librarianship (Weimer and Reehling, 2006). GIS offers other areas of research within LIS beyond geographic information librarianship or utilization of GIS as a tool to measure and analyze library services.

The uses of GIS vary, but put simply GIS allows real-world phenomena to be mapped and analyzed for more informed decisions. The technology has been used in a wide array of disciplines (Blaschke and Merschdorf, 2014), with a great explosion of research in the geohumanities as an increasing amount of historic data becomes or is born digital, as evidenced by the creation of GeoHumanities journal in 2015. Some examples of geohumanities work in libraries include application of GIS to a genealogical information system that embeds spatial analysis into the tracing of migration patterns and family trees (Chang, 2018), the use of desktop GIS to georeference archival aerial 
photographs (Kim, 2018), and the use of GIS to analyze and visualize historic Chinese chronicles (Zhu and Bao, 2015).

Any discussion of analyzing libraries' service area populations with GIS should begin with Koontz's (1997) Library Facility Siting and Location Handbook and her preceding work (Koontz, 1992, 1995). In the more than twenty years since Koontz's pioneering work in using GIS for library location siting, facility location models, and inlibrary use, GIS use in library research has grown as she and colleagues continued to further this area (Jue et al., 1999; Koontz and Jue, 2004; Koontz et al., 2009). This literature review looks even further into the future as more uses for GIS within and outside of all types of libraries are found. Early work was conducted mostly in the U.S., but the GIS library research in this literature review shows many more projects globally than in the 2010 review.

As Xia (2004) indicates, GIS requires a high level of expertise in computers and geography to utilize and uncover significant results. The purpose of this paper is to explore the type of LIS research that does require geospatial technologies software expertise and cartographic and geographic principles to conduct, which is research in which data about the library and its services are analyzed and/or displayed spatially via GIS. The LIS research that is utilizing GIS to analyze library data falls into two primary categories: (1) analysis of library service populations and related adjustments to facilities and services based on user demographics and other variables and (2) analysis of collections, in-library, and other facilities-based use. One way to consider this categorization is that LIS research falling into the first category focuses primarily on variables outside the library, and LIS research falling into the second category focuses primarily on variables inside the library.

\section{Methodology}

\section{Database Information}

One of the databases utilized in the previous study was Library Literature and Information Full Text. The authors discovered that, when attempting to access Library Literature and Information Full Text, they were redirected to Library and Information Science Source, which is owned and maintained by EBSCO. An acquisitions librarian informed the authors that, when EBSCO purchased $\mathrm{H}$. W. Wilson, EBSCO merged their databases with Wilson's, creating new "source" databases. Library Literature and Information Full Text still exists but its content is now contained under this new source database, Library and Information Science Source.

Sources identified in both databases and quantities are listed in Table 1. Thirteen unique categories were identified between both, with four of those being unique only to Library and Information Science Source. Quantities in both columns identify the number of sources searched in each database for a given query based on the category. After retrieving the articles, the authors sorted them into these categories to identify what articles would be relevant to the study. Articles identified as Academic Journal were 
further categorized based on the authors' criteria mentioned in the Results section below.

Table 1. Categorization of Types of Sources in LISS and LISTA Databases <insert Table 1 here>

\section{Literature Review Methodology}

This study reviewed the literature on the use of GIS in library research, searching full text for geographic information system ${ }^{*}$ in two library-related databases available at the researchers' institutions, Library and Information Science Source (formerly Library Literature and Information Full Text, used in the 2010 literature review) and LISTA Library, Information Science \& Technology Abstracts. LISTA indexes over 500 academic journals (Garg et al., 2019) and LISS is the database resulting from the merger of Library \& Information Science Retrospective: 1905-1983 and Library Literature \& Information Science Full text databases (Figureola et al., 2017; Garg et al., 2019). As these were also the two library-related databases at the researchers' institutions, this wide net approach was used to ensure that any article related to utilizing GIS within these library databases would be captured. Other less frequently used derivations of GIS in the United States, such as geographical information systems, would also appear with a full text search of geographic information systems. Also, this was the same methodology used for the 2010 literature review (Bishop and Mandel, 2010), and every effort was made to replicate that study for this one.

The titles and abstracts of these results were analyzed to determine the content of the articles. Articles were marked that related to using GIS as a tool to measure and analyze library services, facilities, and use. Most of the records found with "geographic information system" did not match this categorization scheme. Most of the GIS articles retrieved discuss geographic information librarianship with other papers related to the societal context of geospatial technologies, introducing GIS-enabled library programming and services, and utilizing GIS as a tool in other disciplines besides library services (i.e., the articles in the GIS journals indexed in LISTA).

The initial study search was conducted in September 2019. The authors then conducted an additional review using the same approach for the remaining articles published in the last quarter of 2019 at the end of January 2020 (i.e., publication date filter September 2019 - December 2019).

\section{Results}

After analyzing the titles and abstracts and browsing articles' content, 441 articles qualified from Library and Information Science Source and 432 articles qualified from LISTA Library, Information Science \& Technology Abstracts $(n=873)$. Of these, 345 articles are unique to Library and Information Science Source, 336 articles are unique to LISTA Library, Information Science \& Technology Abstracts, and 96 articles were found 
in both databases. Overall, the search yielded 777 unique articles, which were first screened as to whether or not they mentioned geospatial or geographic information systems in libraries. This screening reduced the number of eligible articles to 449. Articles were then assessed for eligibility to be included in the dataset and coded as ineligible, potentially eligible, and eligible. The code was assigned on the basis of whether the articles contained information on libraries utilizing GIS to improve their services (eligible) rather than just offering the service for use to patrons (ineligible). This list was then reviewed by all authors to determine if potentially eligible articles were eligible or ineligible. Figure 3 outlines the process taken to identify the articles used in this study. This process resulted in 36 unique entries.

Those articles meeting the authors' established requirements were analyzed based on the abstract and categorized using the same categories used in the 2010 literature review (see Table 2):

1) Analyzing service area populations $(n=21 ; 58.3 \%)$, and

2) Managing facilities and collections ( $n=11 ; 30.6 \%)$.

Two new categories were found:

3) Both analyzing service area populations and managing facilities and collections $(\mathrm{n}=2 ; 5.6 \%)$, and

4) Literature review $(n=2 ; 5.6 \%)$.

The 2010 literature review found 34 unique articles, 26 in the analyzing service area population category $(76.5 \%)$ and eight in the managing facilities and collections category $(23.5 \%)$.

Figure 3. Outline of article categorization and selection. $<$ insert Figure 3 here>

Table 2. Categorization of Articles Using GIS in Library Research <insert Table 2 here>

\section{Findings}

The following section discusses the findings from the data collection looking at the articles published per year, a framework of the different types of studies conducted in LIS that use GIS as a tool to measure and analyze library services, facilities, and use data, and a brief review and analysis of those studies.

From a Relatively Stable Number of Articles Per Year to a Constant Swing

Looking at the articles per year (Figures 4 and 5 ) shows relative stability across the previous literature review and greater instability in the number of articles per year in the current literature review. The previous review found 0-2 articles per year for 19922003, a major spike in 2004 ( $n=8$; the highest number of articles per year found in both literature reviews), followed by a growth in the yearly range to 2-4 articles per year for 
2005-2009. The current review found a much wider swing year to year. Starting from the two articles in 2009, there was a jump to five articles in 2010 and six in 2011, then a yearly decline to a low of one article in 2014 , followed by an increase to five articles in 2015. That increase was again followed by a decline to 2-3 articles per year for 20162019.

Figure 4. Breakdown by Year of Articles Using GIS in Library Research from Previous Literature Review <insert figure 4 here>

Figure 5. Breakdown by Year of Articles Using GIS in Library Research from Current Literature Review

<insert figure 5 here>

\section{Categorizing the Research in Libraries Using GIS}

The number of articles in the last decade is about the same as the total of all articles found in the previous review (Bishop and Mandel, 2010), but the distribution of the articles by category has shifted. Analyzing service area populations is reduced to comprising about $2 / 3$ of the articles instead of $3 / 4$ and managing facilities and collections is increased to comprising about $1 / 3$ of the articles instead of $1 / 4$. There is also the addition of the previous literature review and the three articles that fit into both analyzing service area populations and managing facilities and collections. Neither the literature review nor the "both" categories were found in the previous review, so these are two new categories of literature on utilization of GIS in LIS.

Studies That Utilized GIS to Analyze Service Area Populations (Data from Outside Libraries)

In the previous literature review, the discussion begins with Koontz's seminal work on library facility siting (1997). Use of GIS to analyze library facility site locations remains a prolific area of research using GIS in LIS. Koontz et al. (2009) investigate reasoning behind public library closures in a variety of communities, based on a 2000 U.S. Census dataset. Johnston and Bishop (2011) draw attention to utilizing GIS in school libraries to analyze the spaces available to both teachers and students, which would help future planning and design of school libraries. Park (2012a, 2012b) uses GIS to determine actual travel distances to libraries from a patron's home and other statistical and descriptive analyses such as demographics, finding that travel distance to a library influences a patron's decision to physically visit the library. Donnelly (2014) studies the geographic distribution of libraries around the U.S., noting areas of interest where library concentrations are high and low in both service areas and use.

GIS was also used to visualize data related to public library internet connectivity. Bishop, Mandel, and McClure (2011) report on two projects using GIS in this capacity. 
One project used GIS to visualize a national public library internet connectivity dataset. The second project used GIS to visually compare broadband access and speeds at libraries and other anchor institutions across rural counties in Florida.

Library facility site research using GIS is reported around the world. Malec (2012) uses GIS to identify gaps of library services in a coastal region of Slovenia using data based on library physical and mobile locations and population distribution. Vodeb and Vodeb (2015) use GIS technologies to conduct a spatial analysis of the Public Library Network in Slovenia, analyzing the spatial accessibility across the country to expose underserved areas, identify driving times to libraries from patrons' residences.

Several articles report on using GIS to conduct geographic analysis of a community or communities. Sin (2011) uses GIS to identify inequalities and variations among the US's 9000 library systems. They evaluated funding and services against neighborhood income and urbanization levels and found a wide distribution among them, especially in staff with higher education, programs, and digital materials access. Thorne-Wallington (2013) investigates general library access based on library location and other socioeconomic factors in the St. Louis, MO area to show the "role of libraries in providing universal access to new media resources" and raise "new questions about how libraries are distributed across the St. Louis area" (p. 53). Bowen Ayre (2015) discusses the benefits of utilizing geospatial data to enhance library services because it can help libraries understand the communities they serve and their needs.

GIS work beyond the U.S. appeared in this decade of research. Hashmi (2019) uses GIS to survey the geographical characteristics of communities to determine how well libraries in Islamabad, Pakistan, serve their communities through education and political engagement. Vidiček and Novljan (2010) use GIS to add demographic data to geographical data to support community analysis and library service planning in Slovenia.

In addition to using GIS to analyze the geographic characteristics of a community, GIS can be incorporated into community outreach work. Futterman and Michaelson (2012) describe a customer-focused strategy to utilize GIS technologies in increasing and updating library services. Higgs et al. (2013) use GIS to investigate library services areas and how they can improve services for patrons in the UK, particularly in digital services with the aim of promoting digital engagement in libraries throughout the UK. Sweeney (2016) recommends utilizing community organizing systems to manage online systems, recommending GIS for community outreach efforts, determining where users and non-users are, and finding gaps. Lindsay et al. (2016) studied how mapping software could assess the impact of health information literacy outreach programs in medical libraries.

Only including articles indexed by Library and Information Science Source or LISTA leaves out some research known to the authors that bears mentioning. For example, Rosichan (2019) discusses how to use GIS in translating information on 
community outreach programs, to bring services to areas that need it most, and to show what areas are lacking services (Rosichan, 2019). Also, Higgs et al. (2016) published another paper on their work assessing service access in South Wales, UK in Environment and Planning C: Politics and Space, which is not indexed in LISTA or LISS but shows that library research utilizing GIS as a tool for spatial analysis of service area populations is being read by a wider audience than LIS.

As with the previous literature review, this review also found that mapping physical locations of users was not the full extent of GIS use in analyzing service area populations; it is also being used in research on virtual reference. Mon et al. (2009) track the IP addresses of users of a statewide reference librarian chat service, as well as how and why they access the chat to identify patterns across the state. Bishop, Mandel, and McClure (2011) also research the geographic dispersion of users of a statewide chat reference service. Bishop, Sachs-Silveira, and Avet (2011) studied and discussed weaknesses in a Florida reference chat consortium, noting that, while it is cost-saving, not having the local knowledge the user may need is a major weakness. There are likely many studies that conduct research related to geography that do not use GIS and spatial analyses.

Managing Facilities and Collections (Data from Inside Libraries)

There are two primary areas of library research using GIS to analyze and visualize data about facilities and collections: how patrons use the library and collection management. How patrons use the library includes both studies on where patrons are in the library and what they do while they are in the library and studies on how patrons find their way within the facility (wayfinding). In the previous literature review, these articles comprised only a small number of the articles in the Inside Libraries category whereas collection management comprised the majority of the articles in the Inside Libraries category. The results are the opposite now: articles reporting the use of GIS to analyze how patrons utilize the library outnumber articles reporting the use of GIS for collection management.

Regarding library space usage by patrons, Mandel (2010a), introduces MapWindow, an open source GIS, as a free and easy-to-use tool for librarians and LIS researchers to use in analyzing and displaying data about where library users sit, read, congregate, and otherwise use the library facility. Gore (2010) reviews Mandel's proposed methodology. Coyle (2011) describes the benefits and uses of internal mapping of libraries to help librarians understand their patrons' needs and how their libraries operate to increase efficiency and monitor collection development, use, and tracking. Given and Archibald (2015) utilize the visual traffic sweep (VTS) methodology to collect observational data on patrons' in-library use of the facility. Their methodology is designed to help researchers understand users' activities within a library setting to better serve them. Godfrey and Stoddart (2016) suggest advancing from relying on 
desktop GIS technologies to web-based GIS technologies to manage in-library use data.

Another study known to the researchers but not found in the review is a paper that combined the methods described by Mandel (2010a) and Given and Archibald (2015). Mandel (2016) used Given and Archibald's VTS method to collect observational data about where patrons were sitting in an academic library during a study week, then employed Mandel's earlier proposed method for mapping in-library use to visualize the results.

Wayfinding was the focus of only one paper reported in the previous literature review. Here, it is the focus of four papers. Mandel (2010b) uses GIS to analyze and spatially display the routes library users taken as they wayfind through the entry area of a public library facility. Hahn et al. (2011) investigate library use on mobile devices, such as mapping a route to a sought-after item to provide a blueprint for creating wayfinding systems within libraries. Aguilar-Moreno et al. (2016) also report on the development of mobile apps to assist user wayfinding while seeking books in an academic library. Luo (2018) studies habitual wayfinding, identifying repeated patterns of library users as they use the library in order to identify traffic patterns to aid in redesigning academic library spaces. There is another study known to the authors that uses GIS to map library users' routes on the first floor of a public library but did not appear in the search results because it was published in a journal not indexed in LISTA or LISS (Mandel, 2013).

Regarding collection management, Pournaghi (2017) looks at using GIS to study collection maintenance, development, and weeding. They used ArcGIS to create library floor plan maps and individual bookshelf maps to best display the current layouts and evaluate their efficiency in an effort to support redesigned facilities that would improve efficiency and collection management. Shen (2018) uses GIS to map the locations of each book in the library through the library-space information model which includes bookshelves, reading room layouts, and reference desks. This model serves as both a wayfinding resource by helping users accurately find the physical locations of books and a readers' advisory resource because librarians can use this technology to track circulation data and recommend similar titles to inquiries.

\section{Both Categories}

Two studies utilized GIS to analyze both inside library data and outside library data. Lim and Park (2015) developed a database that includes data on library site location planning, service area population demographics, and library space requirements based on the size of the population served. This includes note only the total recommended facility size, but also allocations by department such as reference, children's and storage. Lund (2017) explores the employment opportunities made available to librarians willing to step away from an urban landscape to a rural landscape, comparing the service area populations and collection sizes, as well as salary ranges, for rural and urban libraries. 


\section{Literature Reviews on Utilization of GIS as a Library Research Tool}

The previous systematic literature review on GIS use in LIS identified two main categories of use of GIS in LIS research (Bishop and Mandel, 2010): analyzing service area populations (data from outside libraries) and facilities management (data from inside libraries). Aguilar-Moreno and Grannell-Canut (2013) reviewed the literature on uses of GIS in libraries. They categorized the work into three groups: visualizing information to help libraries in making decisions, search interfaces, and incorporating GIS data as a library resource. Clearly, the second literature review covers broader topics of GIS in LIS than the first. Research such as spatial discovery and spatial data management remain important, but very different than the studies using GIS as a tool. Slow Pace of Growth in Utilization of GIS in LIS Research

Xia (2004) had predicted the emergence of GIS utilization in LIS research because of its benefits, such as generating maps to convey more information than tables and text alone and allowing librarians to spatially analyze library services. In addition to these benefits, GIS software shifted from a mainframe computer to a PC desktop setting to web-based applications, experienced reduction of overall costs and more open source options, and seen advances in usability of the systems, all of which were predicted to make the technology more accessible for librarians to use (Donnelly, 2010).

However, this literature review did not find substantial growth in use of GIS in LIS research as compared to the previous literature review. There has been some growth in the studies published using GIS in library research (from 34 between 1992-2010 to 36 between 2009-2019, not counting the two literature reviews found in this study). The spike in studies published in 2015 is promising, but it was followed by a rapid decline back to 2-3 articles per year for the rest of the period under review. The question of why this pace of growth is slow is a big one for LIS to ask itself.

A study found during this review, but not counted as part of the dataset because it did not actually employ GIS as a tool for library research, looked at factors that lead to an ideal setting for library research using GIS (Pournaghi and Babalhavaeji, 2013). These factors are library type (public, academic, special, children's, and institutional); access to collections; activity level of the library based on services offered, patrons served, and number of staff; collection size and breadth; size and space of the library; equipment in the library; and "compatibility," which includes security, environmental factors, and physical appeal of the building. Based on these factors, Pournaghi and Babalhavaeji found academic libraries to be more appropriate for using GIS.

A search of LISTA for the five library types as subject terms, limited to peer reviewed journals found 6,902 results for "public libraries," 14,535 results for subject "academic libraries," 1,351 results for "special libraries," 282 results for "children's libraries," and 70 results for "institution libraries." Since academic libraries appear to be 
where the majority of library research occurs, that does not seem to be a factor related to the slow growth of utilization of GIS in library research.

\section{Limitations}

The main limitation of this literature review is that the results are from two library literature databases, available at the institution of the authors, and only include the publications indexed within them. Untold numbers of consultation projects may have been conducted at local levels to assess library use and facility site location with GIS, but this paper only reviews the publications indexed in these databases. Using additional databases, inaccessible to these authors at their institution, such as Library and Information Science Abstracts (LISA) might have provided further articles that match the literature review's criteria. In addition, more consultation projects utilizing GIS may be findable when sought through search engines; however, this avenue was not explored for this literature review.

An additional limitation is that this review looked only at library research that used GIS. Other publications exist that detail assessment and other projects libraries undertake in which they utilize geospatial technologies, but that do not constitute research. In a column for Public Libraries, Sharma (2015) reports on how GIS is primarily used in public libraries. Like Bishop and Mandel (2010), Sharma (2015) identifies that GIS is used for in-library usage and collection development (data from inside libraries) and an assessment and strategic planning tool focused on service area analysis (data from outside libraries). Sharma's examples demonstrate practical uses of GIS in library decision-making that do not meet the rigors of empirical research.

\section{Implications}

Over 15 years ago, Xia (2004) predicted an increased use of GIS in LIS research. Ten years ago, Donnelly noted that GIS technology was becoming more accessible to librarians (2010), and Bishop and Mandel (2010) recommended wider use of as a tool in researching library service populations, virtual library services, collections management, facilities management, and wayfinding. Some of that has occurred with the growth in wayfinding research in libraries that uses GIS to visualize the data and the continued work in service population analysis, virtual reference, collections and facilities management.

In 2010, Bishop and Mandel had also suggested that future LIS research using GIS might consider geocaching activities, evaluations of marketing effectiveness, and use of GIS in the LIS curriculum. This review found no research on any of those topics. A review from the past decade (2009-2019) of the LIS research that utilized GIS to visualize variables internal and external to the library facility shows minimal growth from the preceding decade (2000-2009). The authors are left wondering why that is. While we (and the literature) recognize the knowledge and skills required to use GIS as a visualization tool, it is not actually more difficult to use GIS software than it is to use statistical software like SPSS or R. Is it just that the specialized knowledge related to 
geography and cartography is outside the knowledgebase of many LIS researchers? Or that GIS appears more difficult to use? If either of those conditions are true, then why don't LIS researchers partner with GIS specialists in their cities or universities to collaborate on projects that use GIS to analyze LIS data?

There are many areas where GIS can be a useful tool in library research. In addition to the studies enumerated above and in the previous literature review, there are numerous ways libraries can utilize GIS. For example, GIS can be used to research where bookmobiles are needed based on patron demographics and the most efficient routes for them to take through neighborhoods. Libraries could use GIS to research past natural disasters to assist in planning for the response and recovery to future natural disasters and anthropogenic hazards. Libraries could also incorporate GIS into genealogical and historical research as many aspects of this research relates to places and place history. The power of GIS to support library research is almost limitless given the connection of places to many information needs.

We strongly agree with Xia (2004) that, because maps convey more information than tables and text and allow spatial analysis of library facilities and services, GIS should be used as a tool more frequently in LIS. The authors speculate that the specialized geographic knowledge and expertise required to utilize GIS as a tool limits the quantity of LIS research utilizing GIS as a data analysis and display tool. A few authors of papers found in this literature review seemed to be making concerted efforts to make GIS seem accessible to LIS researchers, such as Lund (2017) and Mandel (2010a).

The 2010 review by Bishop and Mandel had also noted that many of the articles in that review lacked details of their methodology and visualization strategies and steps that made replication difficult. That remains an issue today, as the articles reviewed here also lack such details. Some of that may be due to word limits for submissions to peer-reviewed journals so perhaps authors can include appendices or share their methods online through personal websites or social media. For example, Luo (2018) includes an appendix with the steps for how they visualized patron routes in ArcMap.

\section{Conclusion}

The literature of a field is constantly evolving. Ten years ago, a review was published of the literature for uses of GIS in library research (Bishop and Mandel, 2010). This review explored what has been published in this area in the decade since finding that the bulk of the literature in this area remains categorizable into two areas: research looking at variables inside the library and research looking at variables outside the library. Two new categories emerged: research that looks at variables both inside and outside the library (this is, in essence, an expansion of the previous review's findings) and literature reviews in the topic area. There has been a slight change in the breakdown of research that investigates variables inside versus outside the library, with slight growth in the percentage of published papers on library research using GIS to 
investigate variables inside the library and a corresponding slight decline in the percentage of published papers on library research using GIS to investigate variables outside the library. As was found in 2010, the continued proliferation of technology and data analytics within libraries and library researchers still does not appear to be resulting in any substantial growth of the use of GIS as a research tool in LIS. GIS offers many areas of research for LIS so the reasons why GIS is not utilized more as a tool in library research bears further investigation--however, with more training, easier access to data and tools, including open source software, another decade will likely provide new creative uses to evaluate library services and resources.

\section{References}

\section{General References}

Bishop, B. W. and Grubesic, T. H. (2016), Geographic Information: Organization, Access, and Use. Springer, New York.

Blaschke, T. and Merschdorf, H. (2014), "Geographic information science as a multidisciplinary and multiparadigmatic field", Cartography and Geographic Information Science, Vol. 41 No. 3, pp. 196-213.

Byrne, D. and Pickard, A. J. (2016), "Neogeography and the democratization of GIS: a metasynthesis of qualitative research", Information, Communication \& Society, Vol. 19 No. 11 , pp. 1505-1522.

Chang, C. C. (2018), "Hakka genealogical migration analysis enhancement using big data on library services", Library Hi Tech, Vol. 36 No. 3, pp. 426-442.

Figuerola, C. G., Marco, F. J. G., and Pinto, M. (2017). "Mapping the evolution of library and information science (1978-2014) using topic modeling on LISA." Scientometrics, Vol. 112 No. 3, pp. 1507-1535.

Garg, K. C., Kumar, S., and Singh, R. K. (2019). "Coverage and overlap of primary journals indexed by Library, Information Science and Technology Abstracts and Library and Information Science Abstracts." Annals of Library and Information Studies (ALIS), Vol. 65 No. 4, pp. 261-267.

Goodchild, M. F. (1992), "Geographic information science", International Journal of Geographical Information Systems, Vol. 6 No. 1, pp. 31-45. 
Jue, D. K., Koontz, C. M., Magpantay, J. N. and Lance, K. C. (1999), "Using public libraries to provide technology access for individuals in poverty: A nationwide analysis of library market areas using a geographic information system", Library \& Information Science Research, Vol. 21 No. 3, pp. 299-325.

Kim, J. S. (2018), "The application of near-automated georeferencing technique to a strip of historic aerial photographs in GIS”, Library Hi Tech, Vol. 36 No. 1, pp. 43-56.

Koontz, C. M. (1992), "Public library site evaluation and location: past and present market-based modeling tools for the future", Library \& Information Science Research, Vol. 14 No. 4, pp. 379-410.

Koontz, C. (1995), "Using geographic information systems for estimating and profiling geographic library market areas" in Geographic information systems and libraries. University of III. at Urbana-Champaign. Graduate School of Library and Information Science, University of III. at Urbana-Champaign. Graduate School of Library and Information Science, Urbana-Champaign, IL, pp. 181-193.

Koontz, C. and Jue, D. K. (2004), "Customer data 24/7 aids library planning and decision making", Florida Libraries, Vol. 47 No. 1, pp. 17-19.

Pelczar, M., Frehill, L. M., Nielsen, E., and Li, J. (2020). Data File Documentation: Public Libraries in the United States Fiscal Year 2018. Institute of Museum and Library Services: Washington, D.C.

Schuurman, N. (2009). Geographic Information Science (GISc). In D. Gregory, R. Johnston, G. Pratt, M. J. Watts, \& S. Whatmore (Eds.), The Dictionary of Human Geography (5th ed.) (pp. 277-279). Malden, MA: Wiley-Blackwell.

Sharma, D. M. (2015), "Using GIS to Assess Public Libraries", Public Libraries, Vol. 54 No. 6, pp. 19-20.

Tomlinson, R. (1998), "The Canada Geographic Information System," in Foresman, T.W. (Ed.), The History of Geographic Information Systems: Perspectives from the Pioneers, Prentice Hall, Inc., Upper Saddle River, NJ, pp. 21-32.

United States Census Bureau. (2010). 2010 Census. https://www.census.gov/geographies/mapping-files/time-series/geo/tiger-linefile.2010.html 
Wei, F., Grubesic, T. H., and Bishop, B. W. (2015), "Exploring the GIS knowledge domain using CiteSpace", The Professional Geographer, Vol. 67 No. 2, pp. 374-384.

Weimer, K. H. and Reehling, P. (2006), "A new model of geographic information librarianship: Description, curriculum, and program proposal", Journal of Education for Library and Information Science, Vol 47 No. 4, pp. 291-302.

Xia, J. (2004), "GIS in the management of library pick-up books", Library Hi Tech, Vol. 22 No. 2, pp. 209-216.

Zhu, S. and Bao, P. (2015), "The use of geographic information system in the development and utilization of ancient local chronicles", Library Hi Tech, Vol. 33 No. 3 , pp. 356-368.

References on Analyzing Service Area Populations

Bishop, B. W., Mandel, L. H., and McClure, C. R. (2011), "Geographic information systems (GIS) in public library assessment", LIBRES: Library \& Information Science Research Electronic Journal, Vol. 21 No. 1, pp. A1-A18.

Bishop, B. W., Sachs-Silveira, D., and Avet, T. (2011), "Populating a knowledge base with local knowledge for Florida's Ask a Librarian Reference Consortium”, Reference Librarian, Vol. 52 No. 3, pp. 197-207.

Bowen Ayre, L. (2015), "Who's out there? The power of spatial data", Collaborative Librarianship, Vol. 7 No. 2, pp. 96-97.

Donnelly, F. P. (2014), "The geographic distribution of United States public libraries: An analysis of locations and service areas", Journal of Librarianship \& Information Science, Vol. 46 No. 2, pp. 110-129.

Futterman, M. and Michaelson, J. (2012), "Data rules: How mapping technology drives better customer service", Public Library Quarterly, Vol. 31 No. 2, pp. 141-152.

Hashmi, F. A. (2019), "Political discourse: Do public libraries serve as a fertile ground?" Library \& Information Science Research, Vol. 41 No. 3, Online First.

Higgs, G., Jones, S., Langford, M., and Heley, J. (2016), "Assessing the impacts of changing public service provision on geographical accessibility: An examination of 
public library provision in Pembrokeshire, South Wales", Environment and Planning C: Politics and Space, Vol. 36 No. 3, pp. 548-568.

Higgs, G., Langford, M., and Fry, R. (2013), "Investigating variations in the provision of digital services in public libraries using network-based GIS models", Library \& Information Science Research, Vol. 35 No. 1, pp. 24-32.

Johnston, M. P., and Bishop, B. W. (2011), "The potential and possibilities for utilizing geographic information systems to inform school library as place", School Libraries Worldwide, Vol. 17 No. 1, pp. 1-12A.

Koontz, C.M. (1997), Library Facility Siting and Location Handbook, Greenwood Press, Westport, CT.

Koontz, C. M., Jue, D. K., and Bishop, B. W. (2009), "Public library facility closure: An investigation of reasons for closure and effects on geographic market areas", Library \& Information Science Research, Vol. 31 No. 2, pp. 84-91.

Lindsay, J. M., Partee, R. P., Oelschlegel, S., and Leonard, K. (2016), "Mapping the changes to a health information service", Journal of Electronic Resources in Medical Libraries, Vol. 13 No. 3, pp. 124-130.

Lund, B. (2017), "Rural library opportunity zones: Mapping rural library employment opportunities using quantum GIS", Endnotes, Vol. 8 No. 1, pp. 1-12.

Malec, L. (2012), "DOSTOPNOST KNJIŽNIČNIH STORITEV NA OBALNO-KRAŠKEM OBMOČJU" (Slovenian), "Accessibility of Library Services in the Coastal-Karst Region" (English), Knjižnica, Vol. 56 No. 4, pp. 109-128.

Mon, L., Bishop, B. W., McClure, C. R., McGilvray, J., Most, L., Milas, T. P., and Snead, J. T. (2009), "The geography of virtual questioning", Library Quarterly, Vol. 79 No. 4, pp. 393-420.

Park, S. J. (2012a), "Measuring public library accessibility: A case study using GIS", Library \& Information Science Research, Vol. 34 No. 1, pp. 13-21.

Park, S. J. (2012b), "Measuring travel time and distance in library use", Library Hi Tech, Vol. 30 No. 1, pp. 151-169. 
Rosichan, S. (2019), "Application of GIS in mapping of adult literacy outreach programs and potential areas of impact and need", Public Library Quarterly, online first, doi: 10.1080/01616846.2019.1657789

Sin, S.-C. J. (2011), "Neighborhood disparities in access to information resources: Measuring and mapping U.S. public libraries' funding and service landscapes", Library \& Information Science Research, Vol. 33 No. 1, pp. 41-53.

Sweeney, P. (2016), "Using community organizing systems to reimagine library websites”, Computers in Libraries, Vol. 36 No. 4, pp. 12-15.

Thorne-Wallington, E. (2013), "Social contexts of new media literacy: Mapping libraries," Information Technology \& Libraries, Vol. 32 No. 4, pp. 53-65.

Vidiček, M. and Novljan, S. (2010). "UPORABNOST METOD GIS PRI NAČRTOVANJU KNJIŽNIČNIH STORITEV: NEKAJ PRIMEROV" (Slovenian), "Usability of GIS methodology at library service planning: some examples" (English), Knjižnica: Revija za Področje Bibliotekarstva in Informacijske Znanosti, Vol. 54 No. 1/2, pp. 17-38.

Vodeb, V. and Vodeb, G. (2015), "Spatial analysis of the public library network in Slovenia”, Journal of Library Administration, Vol. 55 No. 3, pp. 202-220.

\section{References on Managing Facilities and Collections}

Aguilar-Moreno, E., Montoliu-Colás, R., and Torres-Sospedra, J. (2016), "TECNOLOGÍAS DE POSICIONAMIENTO EN INTERIORES AL SERVICIO DE UNA BIBLIOTECA UNIVERSITARIA: HACIA LA SMART LIBRARY" (Spanish), "Indoor positioning technologies for academic libraries: towards the smart library" (English), El Profesional de la Información, Vol. 25 No. 2, pp. 295-302.

Coyle, A. (2011), "Interior library GIS”, Library Hi Tech, Vol. 29 No. 3, pp. 529-549.

Given, L. M., and Archibald, H. (2015), "Visual traffic sweeps (VTS): A research method for mapping user activities in the library space", Library \& Information Science Research, Vol. 37 No. 2, pp. 100-108.

Godfrey, B. and Stoddart, R. (2018), "Managing in-library use data: Putting a web geographic information systems platform through its paces", Information Technology \& Libraries, Vol. 37 No. 2, pp. 34-49. 
Gore, G. C. (2010), "Identifying the most popular entry routes into a public library using GIS can be a tool to increase ease of navigation and identify placement of marketing materials. A review of Toward an understanding of library patron wayfinding: Observing patrons' entry routes in a public library by Lauren $\mathrm{H}$. Mandel, Library \& Information Science Research, Vol. 32 No. 2", Evidence Based Library and Information Practice, Vol. 5 No. 4., pp. 94-95.

Hahn, J., Twidale, M., Gutierrez, A., and Farivar, R. (2011), "Methods for applied mobile digital library research: A framework for extensible wayfinding systems. Part of special issue Mobile reference: papers from the handheld librarian conferences", Reference Librarian, Vol. 52 No. 1/2, pp. 106-116.

Luo, J. (2018), "Habitual wayfinding in academic libraries: Evidence from a liberal arts college", Library \& Information Science Research, Vol. 40 No. 3/4, pp. 285-295.

Mandel, L. H. (2010a), "Geographic information systems: Tools for displaying in-library use data", Information Technology \& Libraries, Vol. 29 No. 1, pp. 47-52.

Mandel, L. H. (2010b), "Towards an understanding of library patron wayfinding: Observing patrons' entry routes in a public library", Library \& Information Science Research, Vol. 32 No. 2, pp. 116-130.

Mandel, L. H. (2013), "Finding their way: How public library users wayfind", Library and Information Science Research, Vol. 35 No. 4, pp. 264-271.

Mandel, L. H. (2016), "Visualizing the library as place", Performance Measurement and Metrics, Vol. 17 No. 2, pp. 165-174.

Pournaghi, R. (2017), "GIS as a supporting instrument for making decisions about the library sources collection management”, Collection Building, Vol. 36 No. 1, pp. 11-19.

Shen, Y. (2018), "Library space information model based on GIS -- A Case Study of Shanghai Jiao Tong University", Information Technology \& Libraries, Vol. 37 No. 3, pp. 99-110.

References on Both Analyzing Service Area Populations and Managing Facilities and Collections 
Lim, H.-k., and Park, S. J. (2015), "Designing a GIS-based planning support system for a public library building project", Journal of Librarianship \& Information Science, Vol. 47 No. 3, pp. 254-264.

Pournaghi, R. and Babalhavaeji, F. (2015), "The factors and criteria for prioritization of GIS utilization by libraries”, Electronic Library, Vol. 33 No. 2, pp. 181-195.

References on Literature Reviews of Use of GIS in LIS

Aguilar-Moreno, E., and Granell-Canut, C. (2013), "SISTEMAS DE INFORMACIÓN GEOGRÁFICA PARA UNIDADES DE INFORMACIÓN" (Spanish), "Geographic information systems for information units" (English), El Profesional de la Información, Vol. 22 No. 1, pp. 80-86.

Bishop, B. W. and Mandel, L. H. (2010), "Utilizing geographic information systems (GIS) in library research", Library Hi Tech, Vol. 28 No. 4, pp. 536-547. 


\section{A new decade of uses for geographic information systems (GIS) in library} research

Table 1. Categorization of Types of Sources in LISS and LISTA Databases

\begin{tabular}{|l|l|l|}
\hline Source Type & LISS & LISTA \\
\hline Academic Journal & 1120 & 472 \\
\hline Blog Entry & 1 & 1 \\
\hline Book / Monograph & 1021 & 29 \\
\hline & & \\
\hline Conference Papers Collection & 2 & 2 \\
\hline Conference Proceedings Collection & 24 & 57 \\
\hline Country Report & 1 & $\mathrm{n} / \mathrm{a}$ \\
\hline Database & 2 & $\mathrm{n} / \mathrm{a}$ \\
\hline Encyclopedia & 1 & $\mathrm{n} / \mathrm{a}$ \\
\hline Magazine & 965 & 221 \\
\hline Newspaper & 5 & 2 \\
\hline Pamphlet & 1 & $\mathrm{n} / \mathrm{a}$ \\
\hline Report & 10 & 3 \\
\hline Trade Publication & 122 & 45 \\
\hline Total Number of Sources & 3275 & 832 \\
\hline
\end{tabular}

Table 2. Categorization of Articles Using GIS in Library Research

\begin{tabular}{|l|l|}
\hline Category & \# of Articles \\
\hline Analyzing service populations & 21 \\
\hline Managing facilities and collections & 11 \\
\hline Both “Analyzing..." and "Managing..." & 2 \\
\hline Literature review & 2 \\
\hline
\end{tabular}


2

3

4

5

6

7

8

10

11

12

13

14

15

16

17

18

19

20

21

22

23

24

26

27

28

29

30

32

33

34

35

36

37

38

39

40

41

42

43

44

45

46

47

48

49

50

51

52

53

54

55

56

57

58

59

60 


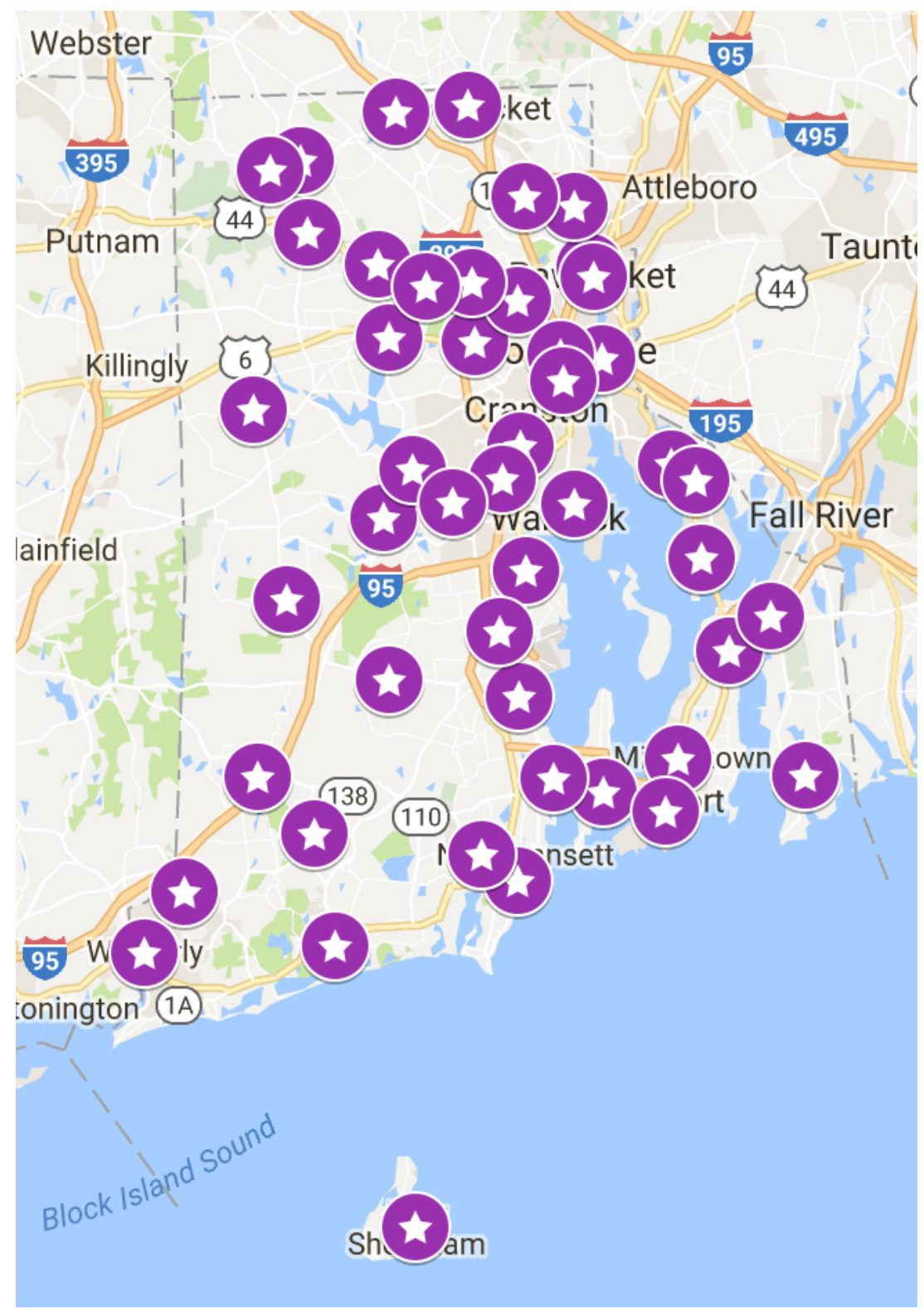




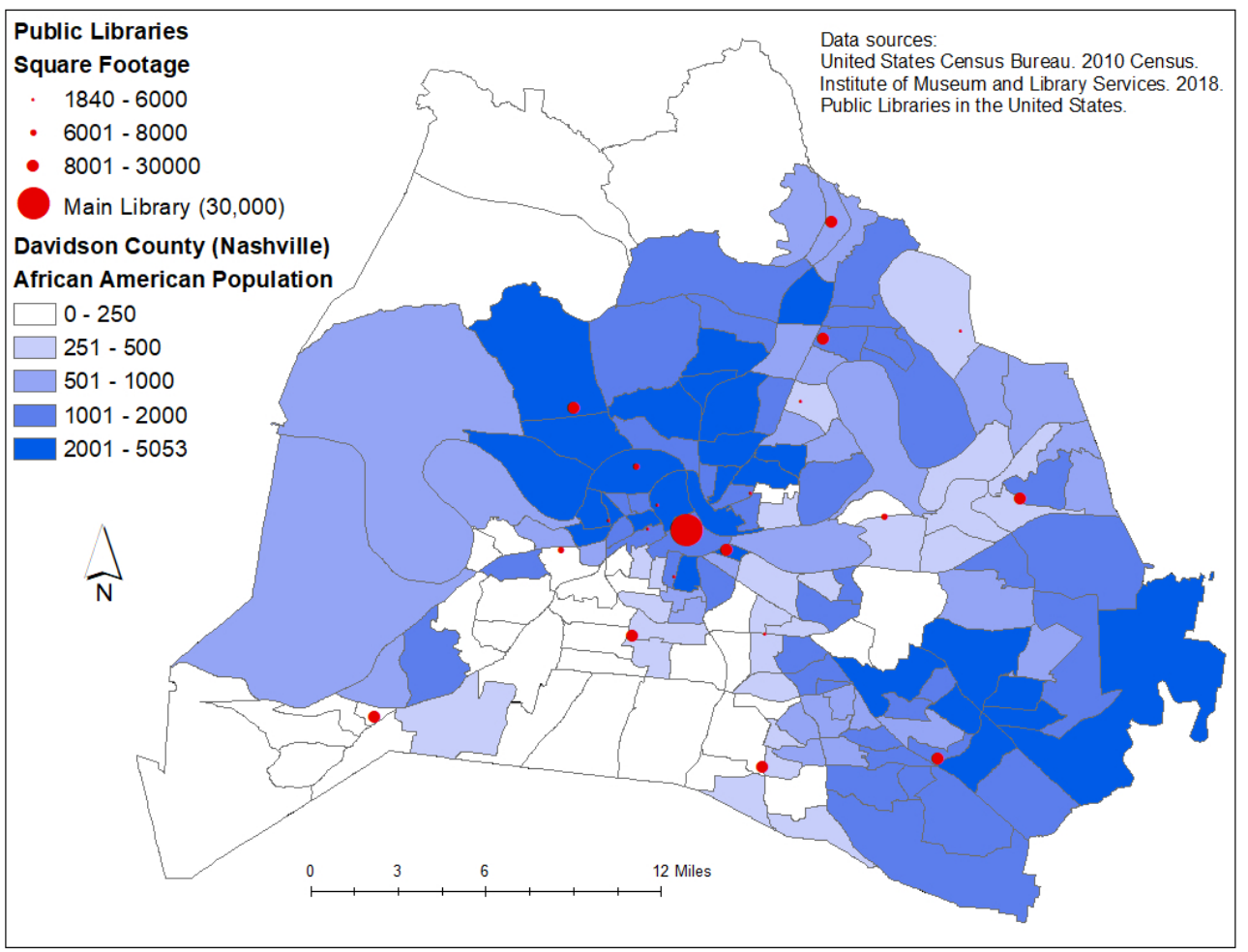




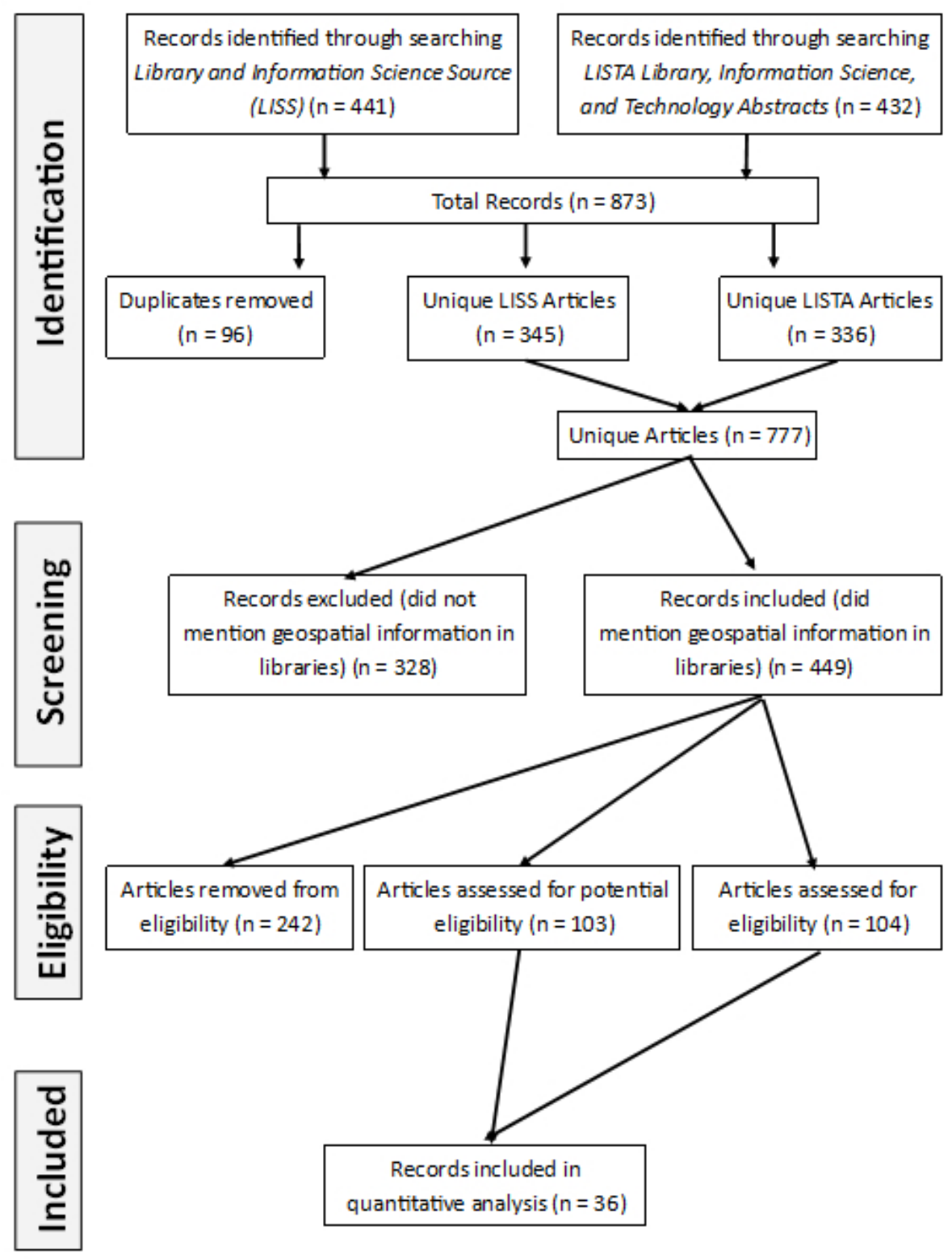




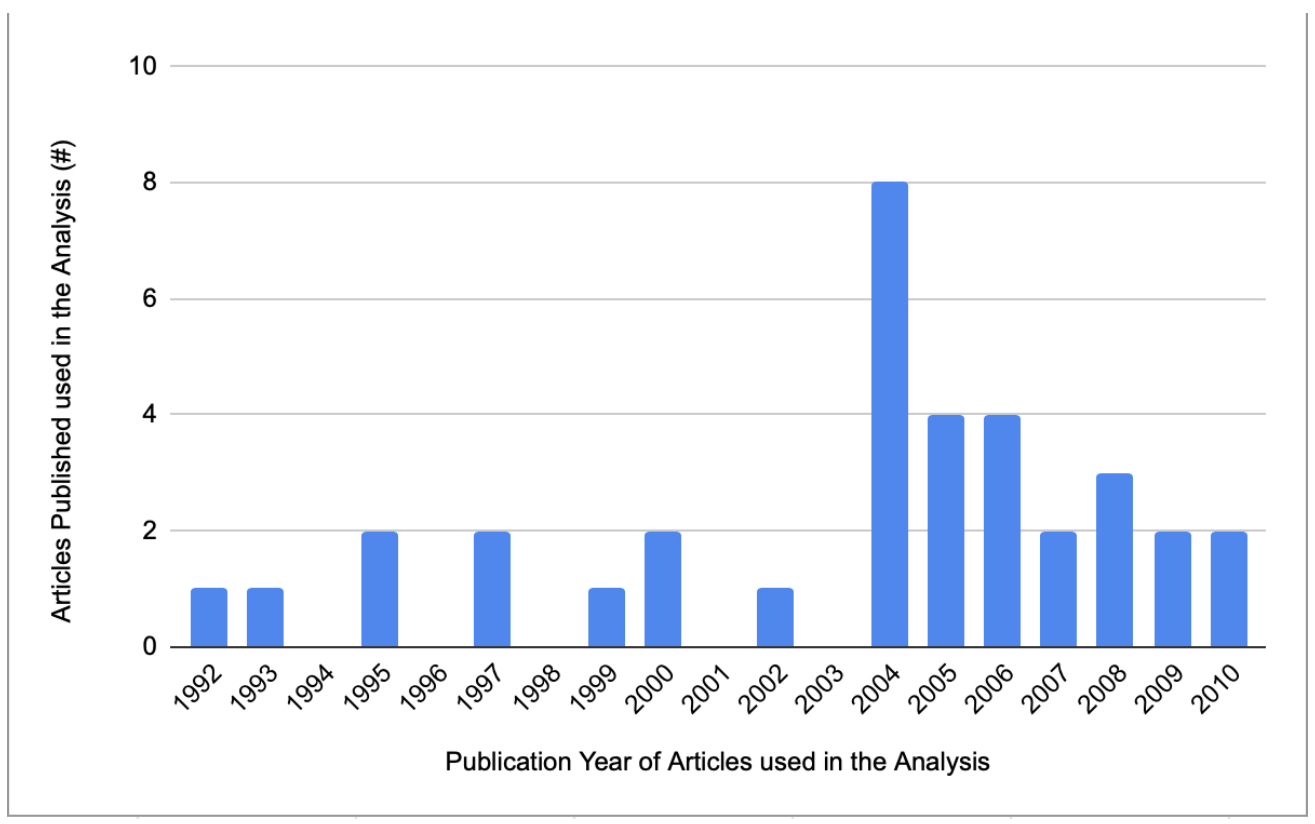




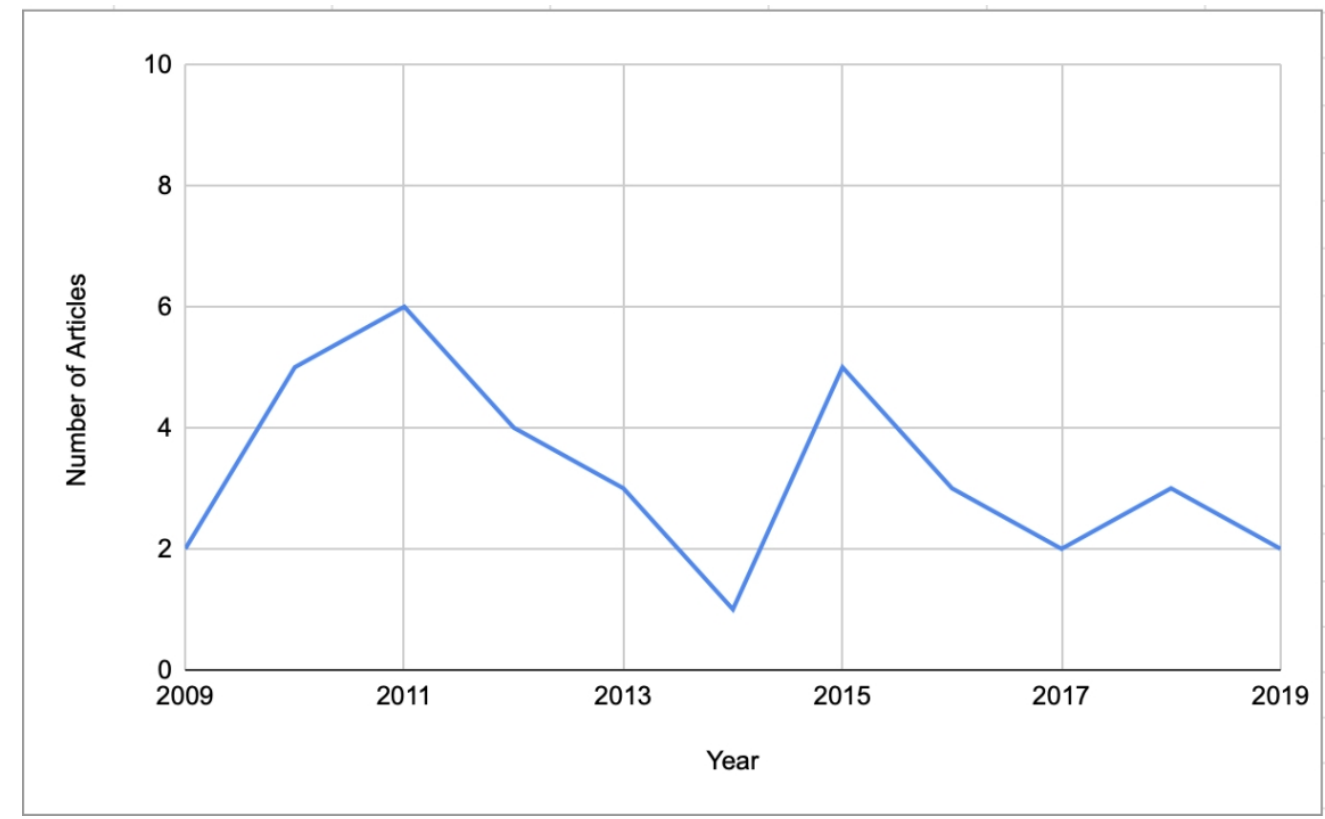

